\title{
Vocimagene Amiretrorepvec
}

National Cancer Institute

\section{Source}

National Cancer Institute. Vocimagene Amiretrorepvec. NCI Thesaurus. Code C91734.

A replication competent retroviral vector, derived from the Moloney murine leukemia virus (MoMLV), encoding a modified form of the yeast suicide gene cytosine deaminase (CD) (Toca 511) used as an antineoplastic adjuvant. Upon transcranial injection, vocimagene amiretrorepvec preferentially enters and transfects tumor cells, and expresses cytosine deaminase, an enzyme that catalyzes the intracellular conversion of the prodrug flucytosine (5-FC) into the antineoplastic agent 5-fluorouracil (5-FU). After administration of 5-FC, the tumor can be eradicated upon activation of 5-FU. 